\title{
PALEOLATITUDE AND CAUSE OF THE SVECOKARELIAN OROGENY
}

\author{
K. J. Neuvonen \\ Neuvonen, K. J. 1974: Paleolatitude and cause of the Svecokarelian orogeny. \\ Bull. Geol. Soc. Finland 46, 75-79.

\begin{abstract}
Paleomagnetic data suggest a paleolatitude of $22^{\circ} \mathrm{N}$ for the Fennoscandian protocontinent during the Svecokarelian orogeny. This is lower than that of the Canadian shield during the same period. Precambrian polar wandering curves of the two continents differ, thus indicating independent drifting. Mutual collisions and periods of separation are suggested by the early history of the two shield areas.
\end{abstract} \\ K. J. Neuvonen, Institute of Geology and Mineralogy, University of Turku, SF- \\ 20500 Turku 50, Finland.
}

\section{Paleolatitude}

Synorogenic gabbro and diorite intrusions are abundant in the Svecofennian territory in Finland and Sweden. Remanent magnetization of some of these intrusives has recently been measured. M. Puranen (1960) demonstrated a distinct magnetic orientation in Ylivieska gabbro in the western part (Pohjanmaa) of Central Finland. Later Stigzelius (1970) showed that the remanence of the Ylivieska gabbro was hard and stable. Cornwell (1968) measured a stable magnetization of Tärändö gabbro in Northern Sweden. Grundström (1967) and R. Puranen (1968) gave magnetic data for Svecofennian (= Svecokarelian, Simonen, 1971) intrusive rocks in Central and Southern Finland. More recently, Pesonen and Stigzelius (1972) have published abundant data concerning the paleomganetism of synorogenic gabbro-diorite intrusions in the Pohjanmaa area.

Additional magnetic data on similar intrusive bodies in SW Finland were collected by the present author and are given in Table 1 . There were more samples but many of them were too weak and unstable to yield reliable results. The hardness of the magnetization of the samples listed was tested by AC and heat treatment. These two methods were also used for cleaning, and both of them revealed an equal direction of the hard magnetization. However, since the AC demagnetization was more effective than the heating 
TABle 1

Remanent magnetization of diorite-gabbro intrusions in SW-Finland

\begin{tabular}{|c|c|c|c|c|c|c|c|c|c|c|c|}
\hline \multicolumn{5}{|c|}{ Original NRM } & \multicolumn{7}{|c|}{ After AC-cleaning $(250-350 \mathrm{Oe})$} \\
\hline $\begin{array}{l}\text { Sample } \\
\text { index }\end{array}$ & Locality & Decl. & Inclin. & $\begin{array}{c}\text { Intensity } \\
10^{-5} \mathrm{EMU}\end{array}$ & Decl. & Inclin. & $\mathrm{R}$ & $\mathrm{k}$ & $\alpha_{95}$ & $(\mathrm{~N})$ & $\begin{array}{l}\text { Intensity } \\
10^{-5} \mathrm{EMU}\end{array}$ \\
\hline 7206 & Moisio, Maaria, Turku ... & $-117^{\circ}$ & $+66^{\circ}$ & 50.0 & $-48^{\circ}$ & $+59^{\circ}$ & 11.67 & 34.98 & 7.4 & 12 & 3.6 \\
\hline 7207 & Kanervamäki, Turku ..... & $-67^{\circ}$ & $+22^{\circ}$ & 435.2 & $-56^{\circ}$ & $+49^{\circ}$ & 11.86 & 10.51 & 13.4 & 13 & 27.2 \\
\hline 7209 & Jalkala, Aura ........... & $-29^{\circ}$ & $+30^{\circ}$ & 3.5 & $-41^{\circ}$ & $+20^{\circ}$ & 10.92 & 120.7 & 4.2 & 11 & 2.0 \\
\hline 7214 & Kruuvais, Paimio ........ & $-40^{\circ}$ & $+65^{\circ}$ & 108.6 & $-28^{\circ}$ & $+19^{\circ}$ & 10.75 & 40.06 & 7.3 & 11 & 12.7 \\
\hline 7215 & Kruuvais, Paimio ........ & $-18^{\circ}$ & $+58^{\circ}$ & 50.2 & $-20^{\circ}$ & $+13^{\circ}$ & 11.90 & 106.2 & 4.2 & 12 & 21.8 \\
\hline 7216 & Suutarla, Karinainen ...... & $+18^{\circ}$ & $+40^{\circ}$ & 18.0 & $-27^{\circ}$ & $+18^{\circ}$ & 11.71 & 37.26 & 7.2 & 12 & 7.7 \\
\hline 7217 & Ojakas, Karinainen ....... & $+35^{\circ}$ & $+74^{\circ}$ & 152.0 & $-15^{\circ}$ & $+23^{\circ}$ & 9.75 & 8.01 & 17.2 & 11 & 13.2 \\
\hline \multirow[t]{2}{*}{$\begin{array}{c}\text { Aver- } \\
\text { age }\end{array}$} & Long. $22.4 \mathrm{E}$, Lat. $60.6 \mathrm{~N}$ & $-32^{\circ}$ & $+58^{\circ}$ & & $-31^{\circ}$ & $+29^{\circ}$ & 6.57 & 14.15 & 16.6 & 7 & \\
\hline & \multicolumn{2}{|c|}{ Pole posit. $\begin{array}{l}\text { Long. } 117^{\circ} \mathrm{W}, \sigma \mathrm{p}=10^{\circ} \\
\text { Lat. } \quad 40^{\circ} \mathrm{N}, \sigma \mathrm{m}=18_{\circ}\end{array}$} & & & & & & & & & \\
\hline
\end{tabular}

TABle 2

Direction of remanent magnetization and paleomagnetic pole sites of the synorogenic Svecokarelian (1 $900 \mathrm{My})$ gabbrodiorite intrusions after AC demagnetization

\begin{tabular}{|c|c|c|c|c|c|c|c|c|c|c|c|c|}
\hline \multirow{2}{*}{ Sampling area } & \multirow[b]{2}{*}{$\begin{array}{l}\text { Long. } \\
\left({ }^{\circ} \mathrm{E}\right)\end{array}$} & \multirow[b]{2}{*}{$\begin{array}{l}\text { Lat. } \\
\left({ }^{\circ} \mathrm{N}\right)\end{array}$} & \multirow[b]{2}{*}{$\begin{array}{c}\text { Decl. } \\
\left({ }^{\circ}\right)\end{array}$} & \multirow[b]{2}{*}{$\begin{array}{c}\text { Incl. } \\
\left({ }^{\circ}\right)\end{array}$} & \multirow[b]{2}{*}{$\alpha_{95}$} & \multicolumn{4}{|c|}{ Paleomagnetic Pole } & \multirow[b]{2}{*}{$\begin{array}{c}\mathrm{P} \\
\left(^{\circ}\right)\end{array}$} & \multirow[b]{2}{*}{$\begin{array}{c}\mathrm{L} \\
\left({ }^{\circ} \mathrm{N}\right)\end{array}$} & \multirow[b]{2}{*}{ References } \\
\hline & & & & & & \begin{tabular}{|l|} 
Long. \\
$\left.{ }^{\circ} \mathrm{W}\right)$
\end{tabular} & $\begin{array}{l}\text { Lat. } \\
\left({ }^{\circ} \mathrm{N}\right)\end{array}$ & $\begin{array}{l}\sigma \mathrm{p} \\
\left.{ }^{\circ}\right)\end{array}$ & $\begin{array}{c}\sigma \mathrm{m} \\
\left({ }^{\circ}\right)\end{array}$ & & & \\
\hline Tärändö, Sweden & 22.5 & 67.1 & -20 & +41 & 14 & 131.3 & 44.6 & 10.3 & 17.0 & 66.5 & 23.5 & Cornwall (1968) \\
\hline Ylivieska, Finland & 24.28 & 64.03 & -28.7 & +38.2 & 6.8 & 117.7 & 43.3 & 4.8 & 8.1 & 68.5 & 21.5 & Pesonen and Stigzelius (1972) \\
\hline Pohjanmaa, " & 24.55 & 64.12 & -27.7 & +29.2 & 13.4 & 120.9 & 37.9 & 8.2 & 14.8 & 74.4 & 15.6 & 》 \\
\hline Tammela, & 23.68 & 60.67 & -36.2 & +50.9 & 3.6 & 100.6 & 52.5 & 3.3 & 4.9 & 58.4 & 31.6 & Grundström (1967) \\
\hline Mikkeli, & 27.25 & 61.70 & -15.2 & +44.6 & 12.2 & 129.7 & 53.1 & 9.7 & 15.3 & 63.8 & 26.2 & $》$ \\
\hline Hyvinkää 》 & 24.6 & 60.6 & -30.5 & +36.1 & 7.3 & 113.8 & 44.1 & 4.9 & 8.5 & 70.0 & 20.0 & Puranen, R. (1968, 1973) \\
\hline SW-Finland, " & 22.44 & 60.60 & $|-31.0|$ & +29.0 & 16.6 & $\mid 117.4$ & 39.7 & 10.0 & 18.3 & 74.5 & 15.5 & This study, Table 2 \\
\hline Average ... & $|24.55|$ & $|62.70|$ & $|-27.1|$ & +38.6 & 7.2 & $|118.9|$ & 45.1 & 5.1 & 8.5 & 68.2 & 21.8 & Fig. 1 \\
\hline
\end{tabular}

$a_{95}=$ the half-angle of the cone of conficence at a probability of $95 \%$ (by site).

$\mathrm{P}=$ distance between sampling site and pole, $\mathrm{L}=$ paleolatitude of the sampling site.

$\left(450^{\circ} \mathrm{C}\right)$, all the heated specimens were also $\mathrm{AC}$ cleaned. The results are given in Table 1.

The gabbro-diorite intrusions mentioned above occupy a tectonically similar, synorogenic position and are considered to be about $1900 \mathrm{My}$ old (Kouvo, 1966). As demonstrated by Table 2, they all show similar magnetic orientation. Table
2 also lists the paleomagnetic pole positions and the calculated distance from the sampling site to the pole. The paleolatitudes of the sampling sites were calculated assuming that the geomagnetic dipole was parallel to the rotation axis. The paleolongitude of the sites is naturally not determined by the magnetic measurements. 
Fig. 1 illustrates the paleolatitude of the area of the Fennoscandian (Baltic) shield $1900 \mathrm{My}$ ago.According to this the Svecokarelian orogenic zone lay between latitudes $18^{\circ}-28^{\circ}$ north of the equator. It has to be noted, however, that only a small part of the shield had formed as a solid continental block by that time. The southwestern part of the present shield was occupied by geosynclinal sediments and volcanics cut by intrusive bodies. They were all younger than the basement in the NE part of the area with an age of about $2500 \mathrm{My}$ (Sakko, 1972).

The svecokarelian sediments met with in Southern and Western Finland and in Sweden are of geosynclinal type and tell very little or nothing at all about the climatic conditions during the period of accumulation. Sediments of the continental margin, e.g. Jatulian quartzites and conglomerates exhibit clear signs of arid and hot or warm climate (Väyrynen, 1928 p. 36-38, Eskola, 1963, Ojakangas, 1965 p. 50). These rocks are older (2 $150 \mathrm{My}$, Sakko, 1972) than the synorogenic intrusive rocks. On the other hand, the younger Jotnian sandstone indicates a warm climatic environment (e.g. Simonen and Kouvo, 1950 and Marttila, 1969). Consequently, the paleolatitude obtained from the magnetic measurements of the synorogenic intrusions is in good agreement with the paleoclimate prevailing during the $1900 \mathrm{My}$ orogeny in Fennoscandia.

The Huronian rock sequence in North America resembles the early Svecokarelian rocks in many respects (e.g. James, 1955, Church and Young, 1972) and the ages of these rocks are similar. The epicontinental Huronian rock sequence is known to be rich in glacial deposites (e.g. in the Gowganda formation, Lindsey, 1969). This indicates accumulation under conditions more polar than those of the Jatulian rocks in Fennoscandia. Paleomagnetic measurements demonstrate that the paleolatitude of the Huronian deposition must have been much higher (about $60^{\circ}$ ) than that in Fennoscandia (Spall, 1971). However, a considerable change

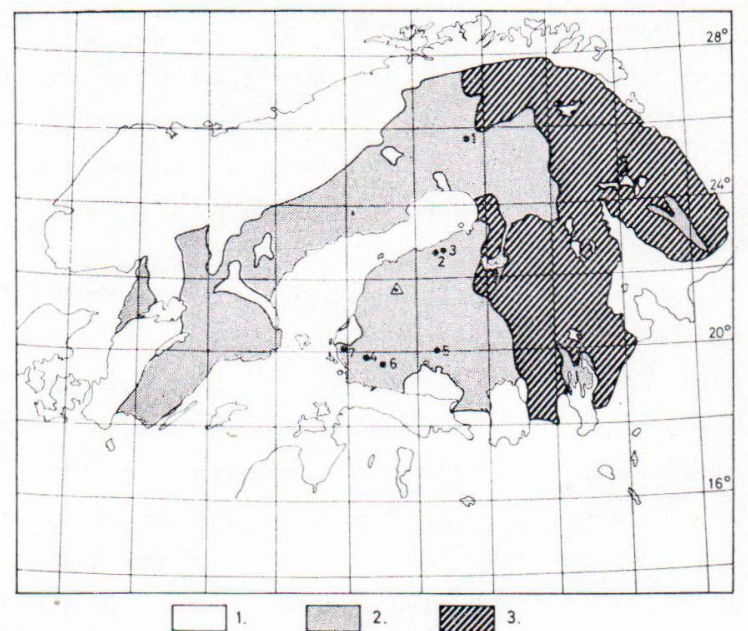

Fig. 1. Paleolatitude of the Fennoscandian (Baltic) shield during the Svecokarelian orogeny (1 $900 \mathrm{My}$ ).

1) Young areas, 2) Svecokarelian zone,

3) Presvecokarelian area (= Sariola continent).

towards a lower latitude is revealed by track 4 on the polar curve of Canada (Irving and Park, 1972).

\section{Drifting speculations}

The apparent polar wandering path found for North America (Robertson and Fahring, 1971, Spall, 1971 and Irving and Park, 1972) and that suggested for Northern Europe (Neuvonen, 1970, 1973 and Spall, 1973) indicate that both blocks were drifting towards the paleoequator between $1900 \mathrm{My}$ and $1300 \mathrm{My}$. The shape of the paths is quite different and gives rise to speculation.

Donaldson et al. (1973) have recently made a reconstruction based on Precambrian paleomagnetic data from the Canadian and Fennoscandian shields. The reconstruction shows that the Grenville and Gothide fronts are roughly colinear. The interpretation is only tentative, but, as the authors point out, there are several interesting features to be considered. The age, geological set up and magnetic orientation of the 
corresponding rock units are very similar in both areas. The similarities are hardly arbitrary and can only be explained by a close spatial connection. The reconstruction shows that the distance between the Canadian and Fennoscandian blocks was not very different from that of the present day. The polar wandering curves of North America (Irving and Park, 1972) and Europe (Neuvonen, 1970) on which the reconstruction was based were calculated assuming a geocentric magnetic dipole. This was certainly not the case and error can be tens of degrees. Consequently, it is quite possible that the two blocks concerned were actually much closer together. On the other hand, old Precambrian parts of Greenland separated the two main blocks from each other. As interpreted by Irving and Park (1972), the hairpins on the polar curve mark large changes in the lateral motion of the Canadian shield and therefore indicate kinematic events. Such loops are not known in the polar curve of Precambrian Fennoscandia (preliminary unpublished data concerning the period from 2150 to $1900 \mathrm{My} \mathrm{col-}$ lected by the author suggest that the movement of this block was relatively slight). The differences observed in the polar wandering curves can be interpreted to suggest independent drifting of the two continents before $1900 \mathrm{My}$ and after $1300 \mathrm{My}$ and rigid intimate connection during the intervening period. A similar close connection has been suggested by Roy (1972) for the Upper Paleozoic, since the paleolatitudes of Eastern North America and Western Europe were almost identical and co-linear during that time. This indicates that the two continents could twice been parts of a single plate, once during the Middle Precambrian (1 900$1300 \mathrm{My}$ ) and once from the Silurian to the Triassic (McElhinny, 1973).

Further studies will throw more light on the problem but as a working hypothesis one could assume that (2 $200 \mathrm{My}$ ) the two landmasses were widely separated prior to the Svecokarelian orogeny, as is indicated by the differences in climatical conditions and paleomagnetic orienta- tion, but that they were forced together during the Penokean-Svecokarelian (1900 My) movements. This intimate connection might have lasted a considerable length of time (about 600 $\mathrm{My}$ ) and terminated during the Jotnian-Mackenzie episode. After a separation of about $600-700$ $\mathrm{My}$, a new collision took place giving birth to the Caledonian mountain chain.

\section{REFERENCES}

Church, W. R. and Young, G. M. (1972) Precambrian geology of Southern Canadian shield with emphasis on the lower Proterozoic (Huronian) of the north shore of Lake Huron. Excursion A 36-C 36, XXIV International Geol. Congress, Montreal.

Cornwell, J. D. (1968) The magnetization of Precambrian rocks from the Tärändö district, Northern Sweden. Geol. Fören. Stockholm Förh. 90, pp. 529 536.

Donaldson, J. A., Irving, E., McGlynn, J. C., and PARK, J. K. (1973) Drift of the Canadian Shield. In Implications of Continental Drift to the Earth Sciences, Vol. 1, Tarling, D. H. and Runcorn, S. K., ed., Academic Press, London and New York.

Eskola, Pentri (1963) The Precambrian of Finland, p. 170. In the Precambrian, Vol. I, Kalervo Rankama, ed., New York.

Grundström, Leo (1967) Eräiden Lounais-Suomen kivilajien magneettinen suuntaus. M. Sc. Thesis, Institute of Geology, University of Turku, Finland.

IRviNG, E. and PARK, J. K. (1972) Hairpins and Superintervals. Can. Journ. Earth Sciences, 9, pp. 13181324.

JAMES, H. L. (1955) Zones of regional metamorphism in the Precambrian of Northern Michigan. Geol. Soc. America Bull. 66, pp. 1455-1488.

Kouvo, Olavi and Tilton, G. R. (1966) Mineral ages from the Finnish Precambrian. Journ. Geology 74, pp. $421-442$.

Lindsey, D. A. (1969) Glacial sedimentology of the Precambrian Gowganda formation, Ontario, Canada. Geol. Soc. Amer. Bull. 80, pp. 1685-1702.

Martitila, Erkki (1969) Satakunnan hiekkakiven sedimentatio-olosuhteista. Ph.lic. thesis, Institute of Geology, University of Turku. 
McElhinny, M. W. (1973) Paleomagnetism and plate tectonics. Cambridge.

Neuvonen, K. J. (1970) Paleomagnetism of the dike systems in Finland V. Remanent magnetization of the Âva intrusives. Bull. Geol. Soc. Finland 42, pp. 101 $-107$.

- (1973) Remanent magnetization of the Jotnian sandstone in Satakunta, SW-Finland. Bull. Geol. Soc. Finland 45, pp. $23-27$.

OJAkangas, Richard W. (1965) Petrography and sedimentation of the Precambrian Jatulian quartzites of Finland. Bull. Comm. géol. Finl. 214.

Pesonen, Lauri J. and Stigzelius, Erik (1972) On Petrophysical and paleomagnetic investigations of the gabbros of the Pohjanmaa region, Middle-West Finland. Geol. Survey Bull. 260.

Puranen, M. (1960) Kivinäytteiden magneettisten ominaisuuksien tutkimusmenetelmistä. Summary: On the determination of magnetic properties of rock samples. Geologinen Tutkimuslaitos. Geotekn. julk. 64, pp. $32-42$.

Puranen, R. (1968) Hyvinkään gabron ja sen naapurikivilajien magneettisista ominaisuuksista. M. Sc. Thesis, Department of Geology and Mineralogy, University of Helsinki.

- (1973) Private communication concerning demagnetization data of Hyvinkää gabbro.
Robertson, W. A. and FAhring, W. F. (1971) The great Logan paleomagnetic Loop - The polar wandering path from Canadian shield rocks during the Neohelikian Era. Canadian Journ. Earth Sciences 8, pp. $1355-1372$.

Roy, J. L. (1972) A pattern of rupture of the eastern North America - Western European paleoblock. Earth and Planet. Science Letters 14, pp. 103-114.

SАкко, Матті (1971) Varhais-karjalaisten metadiabaasien radiometrisiä zirkoni-ikiä. Summary: Radionetric zircon ages on the Early-Karelian metadiabases. Geologi 23, pp. 117-118.

Simonen, Aнti (1971) Das finnische Grundgebirge. Geologische Rundschau 60, pp. 1406-1421.

- and Kouvo, Olavi (1955 Sandstones in Finland. Bull. Comm. géol. Finlande 168, pp. 57-88.

Spall, Henry (1971) Precambrian apparent polar wandering: Evidence from North America. Earth and Planet. Science Letters 10, 273-280.

- (1973) Review of precambrian paleomagnetic data for Europe. Earth and Planet. Science Letters 18, $1-8$.

Stigzelius, E. A. (1970) Ylivieskan gabron magnetoitumisesta. Manuscript. Geological Surv. Finland.

VÄYRYNEN, HEIKKI (1928) Geologische und petrographische Untersuchungen im Kainuugebiete. Bull. Comm. géol. Finlande 78.

Manuscript received, October 24, 1973. 